\title{
PENILAIAN AUTENTIK UNTUK MENINGKATKAN MOTIVASI DAN KETERAMPILAN BERBICARA SISWA
}

\author{
Agung Widiyantoro dan Zamzani \\ SMP Al Azhar 26 Yogyakarta, Universitas Negeri Yogyakarta \\ Email: widiyantoro_agungpbsi05@yahoo.com,zamzani_55@yahoo.com
}

\begin{abstract}
ABSTRAK
Penelitian ini bertujuan untuk meningkatkan motivasi dan keterampilan berbicara siswa kelas VIII A SMP Islam Al Azhar 26 Yogyakarta melalui penerapan penilaian autentik. Jenis penelitian ini adalah penelitian tindakan kelas dengan model Kemmis dan Mc. Taggart. Penelitian ini dilakukan dalam bentuk siklus yang berisi empat tahap yaitu perencanaan, pelaksanaan, observasi, dan refleksi. Teknik pengumpulan data yang digunakan adalah observasi, catatan lapangan, wawancara, tes keterampilan berbicara, dan kuesioner motivasi. Hasil penelitian ini menunjukkan bahwa (1) perhatian, peran aktif, dan antusiasme siswa dalam pembelajaran berbicara mencapai lebih dari 75\%, (2) terjadi peningkatan skor rata-rata keterampilan berbicara siswa dari tahap pratindakan sebesar 34,5 menjadi 63 pada siklus I dan 73,8 pada siklus II, (3) terjadi peningkatan skor ratarata motivasi dan distribusi kategori motivasi berbicara. Tahap pratindakan skor rata-rata motivasi berbicara 62 menjadi 72 pada siklus I, dan 75,12 pada siklus II. Lebih lanjut siswa yang memiliki motivasi berbicara kategori tinggi meningkat, semula berjumlah 1 pada tahap pratindakan menjadi 9 siswa pada siklus I dan 12 pada siklus II. Sementara itu, pada siklus II siswa yang berkategori motivasi berbicara rendah tidak lagi ditemui.
\end{abstract}

Kata Kunci: penilaian otentik, motivasi siswa, interaksi siswa, berbicara

\section{THE AUTHENTIC ASSESSEMENT TO IMPROVE STUDENTS' MOTIVATION AND READING SKILLS}

\begin{abstract}
This research aims to improve the motivation and speaking skills of Grade VIII A students at Al Azhar 26 Islamic Junior High School Yogyakarta by applying authentic assessment. This is an action research with Kemmis dan Mc. Taggart model. This research was conducted in four cycles, namely planning, implementation, observation, and reflection. The data collecting techniques applied in this reserach are observation, field note, interview, speaking skill test, and motivation questionaire. The research shows three results. (1) Students' attention, active participation, and anthusiasm in learning speaking reach more than $75 \%$. (2) There is an increase of the students' speaking skill avarage score, from 34.5 prior an action to 63 at cycle I and 73.8 at cycle II. (3) There is an increase of students' motivation avarage score. The speaking motivation avarage score is 62 at the pre-action, and becomes 72 at cycle I and 75.12 at cycle II. The number of the students with high motivation of speaking skill increases, from 1 at the pre-action to 9 at cycle I and 12 at cycle II. At cycle II, there is no student with low motivation of speaking skill.
\end{abstract}

Keywords: authentic assesesment, students' motivation, students interaction, speaking

\section{PENDAHULUAN}

Dalam rasional pengembangan Kurikulum 2013 (2012:46) dinyatakan bahwa Kurikulum 2013 menekankan proses pembelajaran yang menganut prinsip pembelajaran siswa aktif. Dengan kata lain, selama proses pembe- lajaran berlangsung siswa dituntut aktif untuk melakukan unjuk kinerja. Salah satu bentuk keaktifan siswa dalam proses pembelajaran bahasa bisa ditingkatkan melalui pembelajaran keterampilan berbicara. 
Berkaitan dengan persoalan tersebut, Suparno (2011:820) memaparkan bahwa dalam pembelajaran bahasa Indonesia terdapat budaya yang menjadi penghambat, yaitu budaya belajar siswa masih budaya belajar untuk ujian/mengerjakan soal. Lebih lanjut dijelaskan banyak siswa dapat mengerjakan soal bahasa Indonesia untuk sekadar lulus, tetapi bukan belajar untuk mampu berbahasa Indonesia. Pada akhirnya terjadilah seperti yang disampaikan oleh Sayuti (2011:809-810) bahwa pembelajaran berbicara hanya dilakukan sepintas lalu. Hal ini mengandung maksud bahwa melatih siswa untuk berpidato, berceramah, atau bercerita dianggap sebagai kegiatan yang mubazir. Di samping itu, evaluasi pembelajaran bahasa Indonesia (tes sumatif, formatif, maupun UN) tidak pernah mengevaluasi keterampilan berbicara siswa. Oleh karena itu, tidak mengherankan bila secara perlahan-lahan terbentuklah sikap negatif para siswa dalam mengikuti pembelajaran berbicara. Sikap-sikap yang dimaksud antara lain terkait dengan motivasi dan penguasaan keterampilan berbicara.

Beberapa persoalan di atas tidak bisa dibiarkan berlarut-larut tanpa ada upaya penyelesaian. Sebab, keterampilan berbicara menempati peran strategis bagi keberhasilan siswa dalam kehidupan. Shumin mengungkapkan bahwa berbicara merupakan salah satu elemen inti dalam komunikasi (dalam Richard dan Renandya, 2002:210). Untuk dapat berbicara, seseorang harus menguasai aspek kebahasaan dan aspek makna atau gagasan. Penguasaan akan aspek kebahasaan dan aspek gagasan dalam aktivitas berbicara dapat tercapai jika pembelajaran bahasa Indonesia di sekolah memberikan perhatian yang cukup terhadap kompetensi berbicara (Nurgiyantoro, 2012:399). Hal ini dikarenakan penguasaan bahasa lisan lebih fungsional dalam kehidupan sehari-hari.

Sehubungan dengan permasalahan yang diungkapkan oleh Suparno (2011) dan Sayuti (2011) di atas, dijumpai dan ditemukan permasalahan serupa di SMP Islam Al Azhar 26 Yogyakarta. Permasalahan tersebut telah diamati sejak minggu ketiga pada bulan Maret 2013, terutama di kelas VIII. Pertama, ketika pembelajaran berbicara sedang berlangsung dan guru memberikan penugasan untuk men- ceritakan kembali cerita pendek yang dibaca siswa, ternyata dari 28 siswa di tiap kelas yang bersedia berunjuk kerja tanpa disuruh guru hanya sejumlah 8 siswa. Di sisi lain, 12 siswa lain baru bersedia tampil jika guru meminta dengan berulang-ulang. Bahkan, meskipun sudah diperintah untuk menceritakan kembali, ada 10 siswa tersebut tetap tidak ingin tampil.

Kenyataan semacam itu tidak hanya terlihat dalam satu kegiatan pembelajaran berbicara tersebut tetapi juga dalam kegiatan pembelajaran berbicara lainnya. Permasalahan kedua, dua puluh siswa yang tersebut di atas ketika diminta menunjukkan penampilan bahasa lisan cenderung menolak. Selain itu, ada sebagian siswa yang merasa malu suaranya didengar oleh teman sekelasnya. Ada pula sebagian siswa yang ketika ditanya teman sekelas hanya menjawab dengan pelan dan pesannya sulit dipahami. Sebagian siswa lain pernah berkata, "Pak, pelajaran bahasa Indonesia buat apa sih..", Kan kita sudah bisa ngomong pakai bahasa Indonesia”. Lalu, permasalahan lain di kelas VIII tersebut yaitu sebagian besar siswa ketika berunjuk kerja dalam aktivitas berbicara hanya tampil secara tidak serius.

Kemudian guna mendapat data awal yang lengkap, dilakukan wawancara dengan guru bahasa Indonesia di SMP Islam AL Azhar 26, Budi Purnomo, S.Pd. dan Maria Ulfa, S.S. pada 23 Agustus 2013 diperoleh informasi bahwa siswa kelas VIII rata-rata menganggap pelajaran bahasa Indonesia khusunya keterampilan berbicara tidak begitu penting. Kedua banyak siswa yang kurang semangat mengikuti pembelajaran, dibuktikan dengan kinerja siswa selama mengikuti pembelajaran bahasa Indonesia tidak antusias. Di samping itu, masih terdapat pula siswa yang antusias mengikuti pembelajaran bahasa Indonesia namun jumlahnya masih sedikit. Akhirnya guru pun mengurangi perhatian pada bentuk penilaian kinerja dan lebih menekankan bentuk penilaian objektif dan uraian.

Namun demikian, upaya mendesain dan melaksanakan pembelajaran keterampilan berbicara di kelas harus selalu dilakukan dengan maksimal. Dalam kondisi semacam ini diperlukan cara atau teknik untuk meningkatkan motivasi berbicara siswa tersebut agar pembelajaran bahasa Indonesia terhadap keterampilan 
berbicara dapat diupayakan maksimal dari sisi proses dan hasil. Salah satu tekniknya yaitu penerapan penilaian autentik. Suyata \& Nurgiyantoro (2009:234) mengatakan asesmen yang menekankan kinerja berasumsi bahwa ada sekian banyak unjuk kerja peserta didik yang dapat ditampilkan yang kesemuanya itu lebih dari sekadar ujian tertulis jawaban singkat sebagaimana dalam tes tradisional.

Beberapa data hasil praobservasi dan wawancara di lapangan menunjukkan bahwa perhatian para guru terhadap pembelajaran keterampilan berbicara tidaklah sejalan dengan pendekatan-pendekatan yang diamanatkan oleh kurikulum, terutama pada mata pelajaran bahasa Indonesia. Pembelajaran berbicara di sekolah seringkali tidak merepresentasikan pembelajaran yang autentik dan bentuk tes yang digunakan pun tidak betul-betul mengukur kemahiran berbicara siswa. Dengan kata lain, bentuk tes yang digunakan sudah autentik namun pelaksanaan penilaian autentik belum sepenuhnya dilakukan dengan tepat. Tes-tes untuk mengukur pencapaian siswa kebanyakan cenderung berbentuk tes objektif. Bahkan kompetensi berbicara sering tidak terwakili dalam bentuk tes objektif.

Tes yang tepat untuk mengukur kompetesi berbicara bukanlah tes objektif melainkan tes unjuk kinerja. Hal ini dijelaskan pula oleh Nurgiyantoro (2012:398) bahwa tes kompetensi berbicara haruslah tes yang menuntut siswa berunjuk kerja dan ber-doing something lewat bahasa. Hal ini dikarenakan kompetensi berbicara termasuk keterampilan berbahasa secara produktif sehingga membutuhkan bentuk tes yang benar-benar mengukur kinerja siswa secara nyata. Dengan demikian, tugas atau tes yang cocok untuk kompetensi berbicara adalah penilaian autentik.

Di samping itu, dalam standar penilaian Kurikulum 2013, penilaian autentik merupakan penilaian yang diamanatkan kepada guru agar diterapkan di kelas. Meskipun Kurikulum 2013 belum diterapkan secara menyeluruh di semua jenjang pendidikan, guru perlu untuk mulai menerapkan penilaian autentik tersebut dalam pembelajaran bahasa. Oleh karena itu, para guru akan terbiasa menggunakan penilaian autentik sehingga kualitas penilaian pembelajaran bahasa Indonesia benar-benar mencerminkan kompetensi siswa yang sesungguhnya.

Beberapa permasalahan yang telah diungkap di atas, secara implisit membuktikan bahwa motivasi siswa untuk terlibat dalam pembelajaran keterampilan berbicara masih kurang maksimal. Akibatnya, pembelajaran keterampilan berbicara di kelas menjadi kurang berkualitas. Selain itu, keterampilan berbicara para siswa pun belum sesuai dengan kriteria yang ditentukan. Smith \& Burns (dalam Donough, 2009:61) menjelaskan bahwa salah satu prinsip penilaian autentik adalah memiliki tujuan utama untuk meningkatkan pembelajaran siswa.

Pemilihan lokasi penelitian di SMP Islam Al Azhar 26 Yogyakarta dilatarbelakangi dengan alasan rendahnya motivasi dan kualitas keterampilan berbicaranya siswa. Padahal bahwa sebagian besar siswa kelas VIII dominan menggunakan bahasa Indonesia dalam percakapan di sekolah. Gambaran tersebut diperoleh berdasarkan hasil wawancara dan observasi oleh peneliti kepada guru dan siswa. Idealnya dalam kondisi dan lingkungan semacam itu keterampilan berbicara siswa tentu sudah terasah dengan baik.

Dalam penelitian ini, keterampilan berbicara dipandang perlu ditingkatkan untuk membekali siswa di SMP Islam Al Azhar 26 Yogyakarta dengan kompetensi komunikatif. Keterampilan berbicara yang rendah akan berdampak negatif pada kemampuan siswa berinteraksi dengan orang lain. Hamalik (2011:167168) menyebutkan bahwa penilaian merupakan salah satu cara yang dapat digunakan guru untuk membangkitkan motivasi belajar siswa. Di samping itu, Harlen (melalui Gardner, 2006:61) juga menjelaskan bahwa penilaian merupakan faktor utama yang mempengaruhi motivasi siswa. Memang ada banyak cara yang digunakan untuk meningkatkan motivasi berbicara siswa, misalnya saja penerapan beberapa strategi dan teknik pembelajaran. Namun, dalam penelitian ini yang akan digunakan untuk meningkatkan kualitas pembelajaran berbicara - motivasi dan keterampilan berbicara - siswa adalah penilaian autentik. 


\section{METODE}

Penelitian ini merupakan penelitian tindakan kelas. Acuan yang dijadikan pedoman penelitian ini adalah model penelitian tindakan kelas model Kemmis dan Mc. Taggart (via Madya, 2006:67) yang mencakup perencanaan tindakan, implementasi tindakan dan observasi, serta refleksi.

Setiap siklus pada penelitian tindakan harus melalui empat langkah yang terdiri atas (1) perencanaan, (2) pelaksanaan, (3) observasi, dan (4) refleksi. Penelitian tindakan dilakukan dalam dua siklus. Tiap siklusnya berlangsung maksimal tiga pertemuan (6 x 40 menit). Jika pada siklus pertama kedua variabel sudah menunjukkan peningkatan, siklus kedua tidak dilanjutkan begitu pula sebaliknya.

Penelitian ini dilaksanakan pada semester gasal tahun pelajaran 2013/2014 yaitu pada bulan Februari sampai dengan April 2014 di kelas VIII A SMP Islam 26 Al Azhar Yogyakarta.

Data dalam penelitian ini akan diambil dengan beberapa macam teknik pengumpulan data di antaranya yaitu observasi, kuesioner, catatan harian siswa, catatan lapangan, tes autentik berbicara, dan dokumentasi kegiatan pembelajaran.

Data dalam penelitian ini akan diambil dengan beberapa macam teknik dan instrumen pengumpulan data. (1) Observasi. Observasi digunakan untuk mengetahui perilaku, motivasi, dan kinerja siswa pada saat proses pembelajaran berlangsung. Observasi dilakukan oleh peneliti dan guru pengampu Bahasa dan Sastra Indonesia sebagai kolabolator. Observasi dilakukan dengan lembar observasi yang dilengkapi pedoman observasi dan dokumentasi foto. Observasi juga dilakukan dengan menggunakan catatan lapangan agar segala sesuatu yang terjadi pada saat pengambilan data bisa terangkum. (2) Teknik kuesioner digunakan peneliti untuk memperoleh data motivasi berbicara siswa. Kuesioner terdiri dari dua jenis, yaitu angket pratindakan yang diberikan sebelum tindakan dilakukan untuk mengetahui motivasi berbicara siswa sebelum diberi tindakan, serta angket pascatindakan yang diberikan pada akhir penelitian dengan tujuan untuk mengetahui motivasi siswa dalam pembelajaran berbicara. (3) Catatan lapangan.
Catatan lapangan adalah riwayat tertulis dan deskriptif tentang apa yang dikatakan atau yang dilakukan baik oleh guru maupun siswa dalam situasi pembelajaran dalam suatu jangka waktu. Catatan lapangan digunakan untuk mendeskripsikan kegiatan pembelajaran. Catatan pembelajaran dibuat oleh peneliti berdasarkan pengamatan saat pembelajaran. Deskripsi dalam catatan lapangan diarahkan perhatiannya pada persoalan yang dianggap menarik saat proses pembelajaran berbicara dilakukan. (4) Tes autentik berbicara. Teknik tes berbicara autentik digunakan untuk mendapatkan skor atau nilai keterampilan berbicara siswa. Tes autentik yang digunakan untuk mengukur keterampilan berbicara siswa ini disesuaikan dengan kompetensi dasar yang tercantum di dalam silabus. Tes-tes tersebut antara lain wawancara lisan dengan siswa, menceritakan kembali teks, demonstrasi, dan proyek. Tes-tes tersebut menggunakan pedoman penilaian keterampilan berbicara dari beberapa ahli dengan modifikasi disesuaikan dengan kebutuhan peneliti. (5) Dokumentasi kegiatan pembelajaran. Teknik dokumentasi kegiatan ini diaplikasikan dengan pengambilan foto-foto kegiatan pembelajaran saat penelitian berlansung. Foto-foto tersebut digunakan untuk mendokumentasikan aktivitas pembelajaran dalam bentuk gambar. Di sisi lain, digunakan pula dokumentasi berupa rekaman video untuk merekam aktivitas berbicara siswa pada setiap pembelajaran.

Penelitian ini menggunakan teknik analisis deskriptif kualitatif dan kuantitatif, yaitu untuk mendeskripsikan motivasi berbicara dan keterampilan berbicara sebelum dan sesudah implementasi tindakan. Analisis kualitatif digunakan untuk data kualitatif yang berupa hasil observasi lapangan, catatan lapangan, dan wawancara. Analisis kuantitatif digunakan untuk data kuantitatif yang diperoleh dari hasil tes berbicara sebelum dan sesudah diberi tindakan serta dari kuesioner. Kemampuan berbicara siswa dinilai dengan pedoman penilaian yang sudah ditentukan.

Data berupa hasil observasi lapangan, catatan lapangan, kuesioner, dan skor tes keterampilan berbicara siswa dianalisis menggunakan langkah sebagai berikut. (1) Perbandingan antardata, yakni membandingkan data-data 
dalam setiap informasi untuk mempermudah proses klarifikasi data yang sama. (2) Kategorisasi, yaitu mengelompokkan data-data dalam kategori-kategori yang sesuai. (3) Menyajikan data dalam bentuk tabel dan diagram. (4) Menarik kesimpulan, ialah merangkum penjelasan dari semua data yang sudah dikelompokkan.

Penelitian ini menggunakan empat validitas, yaitu validitas demokratik, validitas hasil, validitas proses, dan validitas dialogik. Pertama, validitas demokratik terkait dengan jangkauan kekolaboratifan penelitian dan pencakupan berbagai pendapat atau saran. Kolaborasi tindakan dapat melibatkan siapa saja yang bersedia untuk berbagi dan sama-sama mengupayakan peningkatan atau perbaikan situasi kerjanya. Dalam validitas demokratik ini, diskusi dilakukan dengan berbagai pihak yang terkait dengan penelitian ini, seperti: guru, kolabolator, dan siswa. Kedua, validitas Hasil. Dalam penelitian ini, validitas hasil dipakai pada saat melakukan refleksi pada akhir pemberian tindakan pertama dimana akan muncul permasalahan baru yang menyebabkan pembelajaran kurang berhasil. Dari hasil tersebut, diterapkan pemecahan masalah pada pemberian tindakan berikutnya sebagai upaya perbaikan bertahap agar mencapai hasil pembelajaran yang maksimal. Ketiga, validitas Proses mengangkat pertanyaan tentang "keterpercayaan" dan "kompetensi" dari penelitian terkait. Kunci pertanyaannya adalah seberapa mampu proses mengendalikan penelitian. Validitas ini tercapai dengan cara peneliti dan guru kolabolator secara intensif bekerjasama mengikuti semua tahap-tahap dalam penelitian. Keempat, validitas Dialogik berkaitan dengan proses tinjauan sejawat. Di sini peneliti melakukan dialog dengan guru kolabolator untuk dimintai pendapat atau gagasannya selama proses penelitian. Pada akhirnya, diharapkan adanya dialog yang kritis/ reflektif sehingga kecenderungan subjektivitas dapat diperkecil.

Reliabilitas dalam penelitian ini adalah dengan cara menyajikan data seperti catatan lapangan, transkrip wawancara, hasil observasi, dan hasil penilaiantes keterampilan membaca cepat. Selain itu, juga akan dilampirkan fotofoto dokumentasi selama proses penelitian berlangsung.
Sesuai dengan karakteristik penelitian tindakan, keberhasilan penelitian tindakan ditandai adanya perubahan menuju arah perbaikan. Indikator keberhasilan tindakan terdiri atas keberhasilan proses dan produk. Indikator keberhasilan proses dapat dilihat dari beberapa hal, yaitu: (1) siswa terlihat antusias terhadap proses pembelajaran, (3) jumlah peran aktif siswa selama proses pembelajaran berlangsung mencapai $75 \%$, (4) kebiasaan buruk atau faktor penghambat yang menganggu siswa dalam keterampilan berbicara berkurang, dan (5) siswa memiliki respon positif terhadap penilaian autentik yang digunakan untuk mengukur pencapaian siswa.

Indikator keberhasilan produk dideskripsikan dari keberhasilan siswa dalam keterampilan berbicara dan meningkatnya motivasi berbicara siswa. Indikator ini didasarkan pada perubahan hasil belajar siswa yang positif baik secara perseorangan atau keseluruhan. Keberhasilan produk ini diperoleh jika nilai rata-rata subjek penelitian meningkat. Untuk mengetahui keberhasilannya, maka dilihat dengan cara membandingkan hasil skor keterampilan berbicara atau motivasi berbicara sebelum dan sesudah tindakan dilakukan.

Selanjutnya, peneliti menetapkan kriteria keberhasilan penelitian tindakan kelas ini meliputi beberapa hal, (1) Skor rata-rata keterampilan berbicara siswa mencapai angka minimal 70, (2) Siswa yang memiliki skor keterampilan berbicara dengan kategori baik mencapai $75 \%$ dari seluruh jumlah siswa, dan (3) Skor rata-rata motivasi berbicara siswa mencapai angka 150 atau 75 (konversi dalam rentang 100).

\section{HASIL DAN PEMBAHASAN \\ Hasil Observasi Kegiatan Berbicara Siklus I}

Pada siklus I, terlihat ada peningkatan dari pertemuan pertama hingga pertemuan ketiga. Pada pertemuan pertama, proses pembelajaran memang terasa masih kurang. Siswa terlihat enggan mengikuti proses pembelajaran. Kondisi itu disebabkan topik dalam kegiatan berbicara kurang dapat membangkitkan hasrat belajar. Pada saat diminta memperagakan peran sebagai $\mathrm{MC}$, guru harus berulang-ulang meminta siswa tersebut tampil. Mereka merasa malu jika pe- 
nampilannya dilihat teman sekelas. Mereka pun tampak malu jika harus tampil secara mandiri. Pada akhir pembelajaran, siswa mengusulkan kepada guru agar pertemuan berikutnya segera melakukan kegiatan diskusi. Hal ini menandakan siswa kurang bersemangat dengan metode pembelajaran pada pertemuan pertama.

Pada pertemuan kedua dan ketiga, proses pembelajaran terlihat lebih baik. Keterlibatan siswa dalam kegiatan berbicara meningkat. Jumlah siswa yang berpendapat dan menanggapi setiap persoalan juga bertambah. Di samping itu, jumlah siswa yang melakukan kegiatan nonverbal berupa meletakkan kepala di meja atau melakukan kegiatan lain di luar konteks pembelajaran cenderung menurun. Pada akhir pembelajaran, siswa mengaku senang dengan topik yang mereka diskusikan.

\section{Keterampilan Berbicara}

Peningkatan skor keterampilan berbicara dilihat dari pratindakan sampai dengan pelaksanaan siklus I berakhir. Skor yang diperoleh pada siklus I ini merupakan hasil pengamatan dimulai dari pertemuan pertama s.d. ketiga. Pada pertemuan pertama dan kedua, siswadiberi kesempatan untuk mengoptimalkan dan mencoba keterampilan berbicaranya tanpa merasa bahwa mereka sedang dinilai. Jadi pada tiap pertemuan ini tidak dikatakan bahwa pembelajaran ini adalah sebuah tes. Upaya yang dilakukan tersebut untuk memenuhi kriteria penilaian autentik. Peneliti lebih menekankan kepada siswa tentang apa yang harus dilakukannya? Bagaimana agar performa siswa baik?

Akhirnya pada pertemuan ketiga, disempurnakanlah penskoran terhadap performa siswa dengan pertimbangan-pertimbangan penampilan yang dilakukan pada pertemuan sebelumnya.

Tabel 1. Statistik Hasil Penilaian Keterampilan Berbicara Siklus I

\begin{tabular}{ccccc}
\hline N & Skor Maks & Skor Min & Mean & SD \\
\hline 25 & 88 & 0 & 63.08 & 21.84 \\
\hline
\end{tabular}

Berdasarkan Tabel 1. tersebut, dapat diketahui bahwa skor rata-rata siswa secara keseluruhan adalah 63,08. Berdasarkan skor rata-rata tersebut ada peningkatan sebesar 28,4 atau 5,56 dibandingkan skor pratindakan. Seiring peningkatan jumlah keterlibatan siswa dalam kegiatan berbicara didapatkan pula peningkatan skor rata-rata yang cukup besar. Pada pratindakan ada 12 siswa yang diketahui tidak melakukan aktivitas berbicara. Sementara itu, 13 siswa lain terlibat aktif berbicara.

Hal di atas menunjukkan bahwa tindakan pada siklus I memberi dampak yang positif terhadap minat dan motivasi siswa untuk berbicara. Akan tetapi, peningkatan tersebut masih belum memenuhi target yang diinginkan sehingga masih harus diadakan upaya lagi pada siklus II.

Tabel 2. Peningkatan Skor Rata-Rata Per Aspek

\begin{tabular}{lccc}
\hline \multicolumn{1}{c}{ Aspek } & $\begin{array}{c}\boldsymbol{M} \\
\text { Pratindak- } \\
\text { an }\end{array}$ & $\begin{array}{c}\boldsymbol{M} \\
\text { Siklus } \boldsymbol{I}\end{array}$ & $\begin{array}{c}\text { Pening- } \\
\text { katan }\end{array}$ \\
\hline Bahasa & 1,36 & 2,28 & 0,92 \\
Isi & 1,40 & 2,40 & 1 \\
P.Nonverbal & 1,28 & 3,52 & 2,24 \\
Kelancaran & 1,48 & 2,88 & 1,4 \\
M Kelas & $\mathbf{5 , 5 2}$ & $\mathbf{1 0 , 0 8}$ & $\mathbf{5 , 5 6}$ \\
\hline
\end{tabular}

Tabel 3. Statistik Aspek Keterampilan Berbicara Siklus I

\begin{tabular}{lccccc}
\hline $\begin{array}{l}\text { Aspek } \\
\text { Keteramp }\end{array}$ & \multicolumn{5}{c}{ Deskriptif Statistik } \\
\cline { 2 - 6 } $\begin{array}{l}\text { ilan } \\
\text { Berbicara }\end{array}$ & N & M & $\begin{array}{c}\text { Skor } \\
\text { Mak } \\
\text { S. }\end{array}$ & $\begin{array}{c}\text { Skor } \\
\text { Min. }\end{array}$ & SD \\
\hline Organisasi & 25 & 2.28 & 4 & 0 & 1.06 \\
Isi & 25 & 2.40 & 4 & 0 & 0.91 \\
Perilaku & 25 & 2.52 & 4 & 0 & 0.92 \\
Kelancaran & 25 & 2.88 & 4 & 0 & 1.05 \\
\hline
\end{tabular}

\section{Motivasi Berbicara}

Data penskoran motivasi berbicara siswa didapat melalui kuesioner motivasi yang diisi ketika pertemuan terakhir di siklus I. Bila dibandingkan dengan tahap pratindakan, hasil skor motivasi berbicara pada siklus I ini telah mengalami perubahan. Perubahan yang dimaksud terjadi pada berkurangnya jumlah siswa yang masuk kategori rendah. Sementara itu, skor siswa kategori motivasi tinggi meningkat $32 \%$. Gambaran mengenai kategorisasi motivasi berbicara siswa ditunjukkan pada Tabel 4 dan 5 . 
Tabel 4. Kategorisasi Motivasi BerbicaraSiswa Siklus I

\begin{tabular}{cccc}
\hline Kategori & Interval & Frekuensi & $\mathbf{( \% )}$ \\
\hline Rendah & $50-100$ & 0 & 0 \\
Sedang & $101-150$ & 16 & 64 \\
Tinggi & $151-200$ & 9 & 36 \\
\hline \multicolumn{2}{c}{ Total } & 25 & 100 \\
\hline
\end{tabular}

Tabel 5. Distribusi Frekuensi Motivasi Berbicara Siswa Siklus I

\begin{tabular}{|c|c|c|c|c|c|c|}
\hline \multirow[b]{2}{*}{ 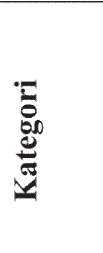 } & \multicolumn{6}{|c|}{ Komponen Motivasi Berbicara } \\
\hline & $\stackrel{\mathscr{\pi}}{\Xi}$ & 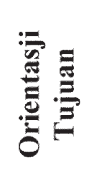 & 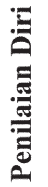 & 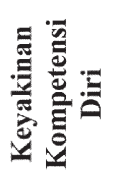 & 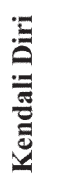 & 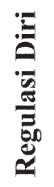 \\
\hline Rendah & 1 & 0 & 0 & 2 & 3 & 4 \\
\hline Sedang & 16 & 17 & 15 & 15 & 17 & 13 \\
\hline Tinggi & 8 & 8 & 10 & 8 & 5 & 8 \\
\hline
\end{tabular}

Sebelum implementasi siklus I dilakukan, guru dan kolaborator berdiskusi untuk menentukan kriteria keberhasilan produk motivasi berbicara. Diskusi tersebut akhirnya membuahkan kesepakatan bahwa penelitian dikatakan berhasil jika skor rata-rata mencapai $\geq 75$. Berdasarkan data penskoran kuesioner motivasi berbicara pada siklus I disimpulkan bahwa keadaan tersebut belum mencapai target.

Pada penelitian ini motivasi berbicara siswa diuraikan ke dalam enam komponen yaitu minat, orientasi tujuan, penilaian diri, keyakinan kompetensi diri, kendali diri, dan regulasi diri. Hasil kuesioner siklus I menunjukkan bahwa ada lima komponen mengalami peningkatan sedangkan satu komponen, yakni orientasi tujuanjustru mengalamai penurunan. Perkembangan aspekaspek motivasi berbicara tersebut dapat dilihat melalui Tabel 6.
Tabel 6.Peningkatan Skor Rata-Rata Kuesioner Motivasi Berbicara

\begin{tabular}{lccc}
\hline $\begin{array}{l}\text { Komponen } \\
\text { Motivasi }\end{array}$ & $\begin{array}{c}\text { Pra } \\
\text { tinda } \\
\text { kan }\end{array}$ & $\begin{array}{c}\text { Siklus } \\
\text { I }\end{array}$ & $\begin{array}{c}\text { Pening } \\
\text { katan }\end{array}$ \\
\hline Minat & 64 & 73 & 9 \\
$\begin{array}{l}\text { Orientasi } \\
\text { Tujuan }\end{array}$ & 76 & 72 & -4 \\
$\begin{array}{l}\text { Penghargaan } \\
\text { Diri }\end{array}$ & 53 & 74 & 21 \\
Keyakinan & 52 & 72 & 20 \\
Kompetensi & & & \\
Diri & & & \\
Kendali Diri & 55 & 69 & 13 \\
Regulasi Diri & 57 & 69 & 11 \\
\hline M Kelas & $\mathbf{6 2}$ & $\mathbf{7 2}$ & $\mathbf{1 0}$ \\
\hline & & & \\
Refleksi & & & \\
\end{tabular}

Pada akhir siklus I, guru (peneliti) bersama guru kolaborator mengevaluasi semua tindakan yang sudah dilaksanakan. Evaluasi bertujuan untuk mencari berbagai hal positif dan negatif yang terjadi selama pelaksanaan siklus I. Hal-hal positif akan dipertahankan pada siklus II, sedangkan hal-hal negatif akan diperbaiki sebagai acuan tindakan pada siklus II. Berikut akan dijabarkan hal-hal positif dan negatif selama pelaksanaan tindakan siklus I.

Berdasarkan hasil refleksi adapun beberapa hal yang diperoleh adalah pertama, selama siklus I, siswa terlihat lebih antusias untuk berbicara. Persentase siswa yang aktif dalam kegiatan diskusi pun meningkat dibanding saat pratindakan. Kedua, kepecayaan diri siswa semakin terbangun. Hal ini tampak pada pertemuan kedua siklus I, siswa yang semula diam dan pasif tetapi saat itu berupaya untuk berpendapat meski dengan kalimat-kalimat singkat. Ketiga, upaya guru memberi motivasi kepada siswa dalam bentuk pemberian contoh-contoh kisah-kisah orator ulung dipandang cukup memberi dorongan siswa untuk berbicara.

Hasil refleksi pelaksanaan siklus I adapula yang bersifat negatif antara lain keantusiasan siswa dalam mengikuti pembelajaran terkadang berakibat pada manajemen waktu yang banyak tersita. Terdapat pula beberapa siswa masih ada yang membuat keributan kecil saat ada siswa yang berbicara, seperti mencele- 
tuk. Hal ini berakibat siswa lain tertawa dan sesekali bersorak.

Selama pengamatan, terdapat empat siswa yang sering berbicara dengan topik di luar pembelajaran. Lebih lanjut, pengetahuan dan pemahaman siswa tentang teknik mengungkapkan pendapat, penolakan, dan sanggahan pendapat belum merata dan maksimal.

Di samping pengamatan di atas, dilakukan pula pengisian kuesioner. Berdasarkan hasil kuesioner motivasi berbicara, meski semua komponen motivasi mengalami kenaikan di siklus I namun masih ada dua komponen belum mencapai skor lebih dari 70. Dua komponen tersebut yaitu locus control, dan regulasi diri. Keenam, Locus control menunjukkan bahwa sebagian siswa belum mampu mengidentifikasi keberhasilan dan kegagalan dalam pembelajaran berbicara. Sementara itu, regulasi diri memberi makna bahwa siswa belum memiliki kesadaran, perhatian, dan tanggung jawab penuh terhadap proses pembelajaran.

\section{Refleksi Produk}

Produk yang direfleksi dapat dilihat pada hasil tes keterampilan berbicara melalui penilaian autentik. Hasil tes keterampilan berbicara menunjukkan bahwa semua aspek keterampilan berbicara meningkat di siklus I. Namun, aspek organisasi bahasa mengalami kenaikan terendah daripada aspek lain. Kemudian, aspek terendah kedua yang mengalami kenaikan yaitu aspek kelancaran. Untuk mengatasi persoalan ini, guru (peneliti) dan kolaborator mencari solusi melalui diskusi dan refleksi. Akhirnya, solusi yang disepakati bersama yakni memberi beberapa pilihan topik kepada siswa dalam kegiatan debat. Topik-topik yang disajikan merupakan topik yang paling dekat kaitannya dengan kehidupan siswa sehari-hari.

\section{Pelaksanaan Penelitian Tindakan Kelas Siklus II}

Berdasarkan observasi selama siklus II, berikut ini ditunjukkan pada Tabel 8 hasil penilaian keterampilan berbicara siswa.
Tabel 7. Statistik Hasil Penilaian Keterampilan Berbicara Siklus II

\begin{tabular}{ccccc}
\hline N & $\begin{array}{c}\text { Skor } \\
\text { Maks. }\end{array}$ & $\begin{array}{c}\text { Skor } \\
\text { Min. }\end{array}$ & M & SD \\
\hline 25 & 93.8 & 43.8 & 73.78 & 12.10 \\
\hline
\end{tabular}

Tabel 8. Statistik Hasil Penilaian Aspek Keterampilan Berbicara Siklus II

\begin{tabular}{rccccc}
\hline \multirow{2}{*}{$\begin{array}{l}\text { Kspek } \\
\text { Keterampilan } \\
\text { Berbicara }\end{array}$} & N & $\begin{array}{c}\text { Deskriptif Statistik } \\
\text { Maks }\end{array}$ & $\begin{array}{l}\text { Skor } \\
\text { Min }\end{array}$ & M & SD \\
\hline Organisasi & 25 & 4 & 1 & 2.60 & 0.82 \\
Isi & 25 & 4 & 2 & 3.00 & 0.65 \\
Perilaku & 25 & 4 & 2 & 3.00 & 0.65 \\
Kelancaran & 25 & 4 & 2 & 3.36 & 0.64 \\
\hline
\end{tabular}

Berdasarkan Tabel 8 tersebut, dapat diketahui bahwa skor rata-rata siswa secara keseluruhan adalah 73,78. Skor rata-rata tersebut menandakan ada peningkatan sebesar 10,8 dibandingkan skor siklus I. Tabel di atas juga menginformasikan bahwa selama siklus II berlangsung semua siswa sudah memiliki skor keterampilan berbicara. Hal ini berarti semua siswa di kelas VIII A telah bersedia untuk berunjuk kerja berbicara melalui kegiatan debat. Keadaan tersebut menunjukkan bahwa tindakan pada siklus II memberi dampak yang positif terhadap motivasi berbicara siswa dan keterampilan berbicara.

Selain itu, informasi mengenai skor rata-rata tiap aspek keterampilan berbicara pun meningkat kecuali aspek perilaku nonverbal. Berikut disajikan peningkatan skor rata-rata tiap aspek keterampilan berbicara siklus I dan siklus II.

Tabel 9. Peningkatan Skor Rata-Rata Keterampilan Berbicara Siklus I dan II

\begin{tabular}{lccc}
\hline Aspek & $\begin{array}{c}\text { M } \\
\text { siklus I }\end{array}$ & $\begin{array}{c}\text { M } \\
\text { siklus II }\end{array}$ & $\begin{array}{c}\text { Pening } \\
\text { katan }\end{array}$ \\
\hline Bahasa & 2,28 & 2,60 & 0,32 \\
Isi & 2,40 & 3,00 & 0,60 \\
Perilaku & 3,52 & 3,00 & $-0,52$ \\
Nonverbal & & & \\
Kelancaran & 2,88 & 3,36 & 0,48 \\
\hline M kelas & $\mathbf{1 1 , 0 8}$ & $\mathbf{1 1 , 9 6}$ & \\
\hline
\end{tabular}




\section{Motivasi Berbicara Siswa}

Motivasi berbicara siswa pada siklus II ini merupakan salah satu produk akhir dalam penelitian ini. Skor rata-rata motivasi pada siklus II ini menunjukkan bahwa penilaian autentik yang diterapkan membawa dampak positif bagi perkembangan motivasi dan keterampilan berbicara siswa. Berikut ini disajikan rangkuman hasil penskoran kuesioner motivasi.

Tabel 10. Kategorisasi Motivasi Berbicara Siklus II

\begin{tabular}{lccc}
\hline Kategori & Interval & Frek & $\mathbf{\%}$ \\
\hline Rendah & $50-100$ & 0 & 0 \\
Sedang & $101-150$ & 13 & 52 \\
Tinggi & $151-200$ & 12 & 48 \\
\hline & Total & $\mathbf{2 5}$ & 100 \\
\hline
\end{tabular}

Tabel 11. Distribusi Frekuensi Motivasi Berbicara Siklus II

\begin{tabular}{|c|c|c|c|c|c|c|}
\hline \multirow[b]{2}{*}{ 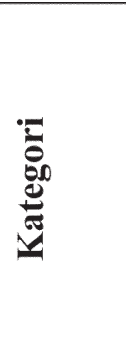 } & \multicolumn{6}{|c|}{$\begin{array}{c}\text { Komponen Motivasi } \\
\text { Berbicara }\end{array}$} \\
\hline & 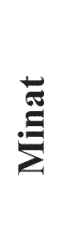 & 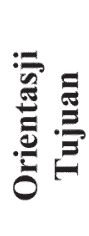 & 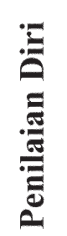 & 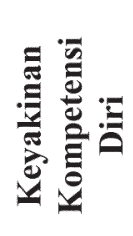 & 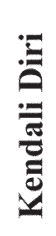 & 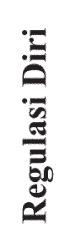 \\
\hline Renda & 0 & 0 & 0 & 0 & 1 & 1 \\
\hline Sedang & $\begin{array}{l}1 \\
6\end{array}$ & 11 & 16 & 13 & $\begin{array}{l}1 \\
9\end{array}$ & 15 \\
\hline Tinggi & 9 & 14 & 9 & 12 & 5 & 9 \\
\hline
\end{tabular}

Tabel 12. Peningkatan Skor Rata-Rata Kuesioner Motivasi Berbicara Siklus II

\begin{tabular}{lccc}
\hline $\begin{array}{l}\text { Komponen } \\
\text { Motivasi }\end{array}$ & $\begin{array}{c}\text { Siklus } \\
\text { I }\end{array}$ & $\begin{array}{c}\text { Siklus } \\
\text { II }\end{array}$ & $\begin{array}{c}\text { Pening } \\
\text { katan }\end{array}$ \\
\hline Minat & 73 & 75 & 2 \\
$\begin{array}{l}\text { Orientasi } \\
\text { Tujuan }\end{array}$ & 72 & 76 & 4 \\
$\begin{array}{l}\text { Penghargaan } \\
\text { Diri }\end{array}$ & 74 & 75.2 & 1.2 \\
Keyakinan & 72 & 78.7 & 6.7 \\
Kompetensi & & & \\
Diri & & & \\
Kendali Diri & 69 & 70.5 & 1.5 \\
Regulasi Diri & 69 & 73.3 & 4.3 \\
\hline M Kelas & $\mathbf{7 2}$ & $\mathbf{7 5 . 1 2}$ & $\mathbf{3 . 1 2}$ \\
\hline
\end{tabular}

\section{Refleksi}

Secara umum pembelajaran keterampilan berbicara dengan menggunakan penilaian autentik pada siklus II menunjukkan adanya perbedaan dengan siklus I. Perbedaan ini dapat dilihat dari aktivitas pembelajaran yang dilakukan oleh siswa. Siswa terlihat lebih antusias dan tertarik dalam mengikuti proses proses pembelajaran berbicara di kelas. Hal yang menjadi dasar asumsi adanya peningkatan proses tersebut adalah jumlah siswa yang terlibat dalam kegiatan debat meningkat yakni mencapai $80 \%$, tingkat dan persentase siswa yang pasif menurun dengan signifikan.

Secara produk, keberhasilan penilaian autentik dalam upaya meningkatkan keterampilan berbicara siswa ditunjukkan dengan skor rerata tes keterampilan berbicara siklus II yang mengalami peningkatan dari tiga kategori. Akan tetapi ada satu kategori keterampilan berbicara yang menurun. Meskipun demikian, rerata keterampilan berbicara kelas secara umum meningkat.

Peningkatan Keterampilan dan Motivasi Berbicara Siswa melalui Penilaian Autentik

Tabel 13. Peningkatan Rata-Rata Skor Aspek Keterampilan Berbicara

\begin{tabular}{lcccc}
\hline Aspek & $\begin{array}{c}\text { Pratin } \\
\text { dakan }\end{array}$ & $\begin{array}{c}\text { M } \\
\text { siklus I }\end{array}$ & $\begin{array}{c}\text { M } \\
\text { siklus II }\end{array}$ & $\begin{array}{c}\text { Pening } \\
\text { katan }\end{array}$ \\
\hline Bahasa & 1.36 & 2.28 & 2.60 & 1.24 \\
Isi & 1.40 & 2.40 & 3.00 & 1.60 \\
Perilaku & 1.28 & 3.52 & 3.00 & 1.72 \\
Nonverbal & & & & \\
Kelancaran & 1.48 & 2.88 & 3.36 & 1.88 \\
\hline M kelas & $\mathbf{1 . 3 8}$ & $\mathbf{2 . 5 2}$ & $\mathbf{2 . 9 5}$ & $\mathbf{1 . 5 7}$ \\
\hline
\end{tabular}

Pada kategori keterampilan berbicara ini, peningkatan skor keterampilan berbicara dilihat dalam empat aspek, yaitu aspek organisasi bahasa, isi, perilaku nonverbal, dan kelancaran. Skor ideal per aspek adalah 4, sedangkan skor ideal untuk skor rata-rata kelas adalah 16 . Target penelitian ini adalah skor rata-rata siswa mencapai 70 atau 11,20. Berdasarkan peningkatan skor keterampilan berbicara tersebut, maka dapat dikatakan bahwa penggunaan penilaian autentikdapat meningkatkan keterampilan siswa dalam diskusi dan debat. Berikut ini disajikan 
diagram batang untuk memperoleh visualisasi peningkatan skor keterampilan berbicara siswa.

\section{Peningkatan Motivasi Berbicara}

Peningkatan motivasi berbicara siswa dilihat melalui skor hasil pengisian kuesioner motivasi, observasi situasi pembelajaran, dan observasi kegiatan berbicara. Ketiga hal tersebut masing-masing disajikan dalam tabel dan gambar berikut untuk memperoleh gambaran peningkatan sejak pratindakan hingga akhir siklus II.

Tabel 14. Kategorisasi Skor Motivasi Berbicara pada Pratindakan, Siklus I, dan Siklus II

\begin{tabular}{|c|c|c|c|}
\hline \multirow[b]{2}{*}{ 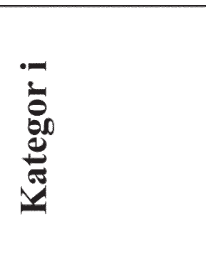 } & \multicolumn{3}{|c|}{ Fekuensi } \\
\hline & 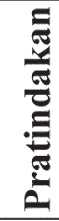 & 点 & 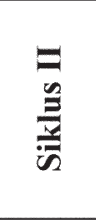 \\
\hline Rendah & 5 & 0 & 0 \\
\hline Sedang & 19 & 16 & 13 \\
\hline Tinggi & 1 & 9 & 12 \\
\hline S. rerata $(100)$ & 62 & 72 & 75.12 \\
\hline
\end{tabular}

Berdasarkan Tabel 14 diperoleh informasi bahwa keadaan motivasi berbicara siswa telah mengalami perubahan pada tiap tahap. Pada pratindakan siswa yang mendapat skor tinggi hanya satu sedangkan masih ada siswa yang mendapat skor rendah. Setelah tindakan dilakukan pada siklus I berlanjut ke siklus II didapat kesimpulan bahwa jumlah siswa yang skornya berkategori rendah atau sedang semakin berkurang dan skor berkategori tinggi semakin meningkat. Hal ini menunjukkan bahwa tindakan yang diberikan dalam penelitian dapat memicu perubahan sikap siswa dalam pembelajaran berbicara. Sikap tersebut ditandai dengan peningkatan peran aktif, perhatian, dan antusiasme siswa dalam kegiatan berbicara.

\section{Pelaksanaan Penelitian Tindakan Kelas melalui Penerapan Penilaian Autentik}

Penilaian autentik merupakan sebuah penilaian yang terintegrasi dalam proses pem- belajaran. Penilaian tersebut mensyaratkan bahwa pencapaian prestasi siswa tidak hanya semata-mata diukur melalui ranah kognitif atau pengetahuan saja tetapi sikap dan keterampilan. Tiga ranah tersebut yang dijadikan acuan untuk menentukan pencapaian prestasi siswa sesuai tujuan pembelajaran. Hal ini karena penilaian autentik merupakan penilaian yang menuntut kemampuan peserta didik untuk mendemonstrasikan pengetahuannya secara nyata dan bermakna (Nurgiyantoro, 2011:23). Dengan demikian, indikator keberhasilan penerapan jenis penilaian autentik ini terletak pada kualitas proses dan produk pembelajaran.

Pembelajaran berbicara dikatakan berhasil jika tingkat partisipasi siswa mencapai $\geq 75 \%$. Sebelum peneliti atau guru melakukan tindakan penerapan autentik dalam pembelajaran berbicara di kelas VIIIA, tercatat data bahwa peran aktif siswa hanya mencapai $50 \%$. Artinya dari 25 siswa yang ada di kelas hanya 12 siswa yang bersedia untuk berbicara.

\section{Antusiasme Siswa}

Hasil penelitian selama siklus I sampai dengan siklus II ini menunjukkan bahwa antusiasme terus mengalami peningkatan. Pada siklus I tercatat bahwa frekuensi siswa yang memiliki antusiasme dalam pembelajaran bermula 11 menjadi 16 di akhir siklus I. Selanjutnya, persentase siswa yang memiliki antuasiasme hingga pada akhir siklus II sudah mencapai $80 \%$. Hal ini menunjukkan bahwa penilaian autentik yang diterapkan membawa perubahan positif bagi siswa.

Perhatian yang dimaksud dalam penelitian ini adalah perhatian siswa terhadap penjelasan guru dan siswa lain saat di kelas. Pada siklus I persentase siswa yang memiliki perhatian sebanyak $60 \%$. Kemudian terus mengalami perubahan hingga mencapai $72 \%$ di akhir siklus I. Selanjutnya pada siklus II pun persentase perhatian siswa terus bertambah. Pada akhir siklus II persentasenya pun mencapai $84 \%$.

Suasana pembelajaran berbicara siswa mengalami peningkatan. Pascasiklus II antusiasme, perhatian, dan peran aktif siswa mencapai $85 \%$. Di samping itu, beberapa hal lain yang memengaruhi tingginya kualitas keterampilan berbicara pun dapat dikatakan mengalami ke- 
cenderungan naik. Dengan demikian, seiring meningkatnya kualitas proses pembelajaran, meningkat pula motivasi berbicara siswa dan keterampilan berbicara siswa.

\section{Peningkatan Skor Komponen Motivasi Ber-} bicara

Minatdalam penelitian ini dimaknai sebagai minat siswa terhadap pembelajaran berbicara. Moreno (2010:334) mengatakan bahwa siswa dapat dimotivasi dengan cara mendesain aktivitas pembelajaran yang selaras atau sesuai dengan minat tertentu pada siswa. Ketika siswa merespons positif lingkungan belajar, ia akan mendapat minatyang membangkitkan motivasi berbicara.

Berdasarkan pendapat di atas, pada tahap pratindakan aspek minatini belum sepenuhnya muncul di siswa kelas VIII A. Hal demikian bisa dilihat melalui skor aspek minat sebesar 64 . Setelah diadakan tindakan di siklus I dan siklus II skor pada aspek ini mengalami peningkatan menjadi 75. Dengan demikian, upaya peningkatan melalui penilaian autentik dapat dikatakan membawa pengaruh positif. Sebagian besar siswa telah merespons pembelajaran berbicara dengan positif. Hal ini ditunjukkan pula dengan meningkatnya peran aktif, perhatian, antusiasme para siswa.

\section{Orientasi Tujuan}

Tujuan Orientasidalam penelitian ini dimaknai dengan cara pandang siswa terhadap tujuan pembelajaran. Pada pratindakan skor goal orientation ini sebenarnya sudah tinggi atau baik. Aspek motivasi ini memiliki skor 76. Hal ini dikarenakan penjelasan guru mengenai tujuan pembelajaran berbicara yang hendak dicapai dapat dipahami siswa dengan baik. Namun, pada siklus I skor aspek motivasi ini justru menurun empat poin menjadi 72 . Kemudian di siklus II kembali mengalami kenaikan menjadi 76.

Berdasarkan hasil refleksi akhir siklus I diperoleh informasi bahwa tujuan pembelajaran yang ditetapkan nampak susah untuk dicapai siswa. Ada kekhawatiran dari siswa bahwa tujuan tersebut akan susah dicapai terlebih dalam kegiatan diskusi. Namun, selama pertemuan di siklus I berlangsung guru selalu meyakinkan kepada siswa bahwa keterampilan berbicara tersebut bisa diraih dengan berlatih.

\section{Penghargaan Diri}

Penghargaan diri ini mengacu kepada kepercayaan diri dan keyakinan siswa bahwa ia merasa dapat belajar dengan baik. Kondisi penghargaan diri siswa pada pratindakan dikatakan rendah yaitu 53. Hal ini berarti sebagian besar siswa kurang memiliki kepercayaan diri dan keyakinan yang tinggi tentang keterampilan berbicara mereka. Hal ini ditunjukkan pula melalui hasil penilaian praktik berbicara siswa. Berdasarkan rubrik penilaian jumlah siswa yang tidak berperan aktif berbicara pada pratindakan berjumlah 13. Dengan demikian, ke-13 siswa tersebut tidak mendapatkan skor keterampilan berbicara. Di samping itu, hasil observasi menunjukkan pula tingkat perhatian, antuasiasme, peran aktif, dan situasi pembelajaran pada pratindakan masih kurang memuaskan. Namun, setelah tindakan berlangsung baik pada siklus I dan II terjadilah kenaikan skor pada aspek ini menjadi 75,2. Akhirnya, kenaikan skor tersebut berarti bahwa upaya peningkatan motivasi berbicara dengan penilaian autentik dikatakan berhasil.

\section{Kepercayaan Kompetensi Diri}

Kepercayaan kompetensi diri mengacu kepada kemampuan siswa untuk memperkirakan keberhasilannya dalam melakukan tugas belajar. Aspek ini ditandai dengan pernyataan "saya bisa" dan "saya tidak bisa". Berdasarkan Anderson dan Bourke dalam Harlen (2006:67) dijelaskan bahwa pengalaman kegagalan atau keberhasilan siswa dalam mengerjakan tugas belajar akan mempengaruhi self eficacy. Hasil kuesioner motivasi berbicara menunjukkan bahwa aspek self eficacy ini mengalami peningkatan yang paling besar dibanding dengan aspek motivasi lain.

Pada pratindakan skor rata-rata self eficacy sebesar 52. Lalu pada siklus I mengalami kenaikan sebesar 72 dan skor pada siklus II menjadi 78,7. Seperti yang diungkapkan di atas, sebagian besar siswa selama penerapan tindakan ternyata selalu memiliki pengalaman berhasil dalam kegiatan diskusi. Kenyataan tersebut didukung dengan hasil pengamatan 
situasi pembelajaran yang menyatakan bahwa tingkat peran aktif siswa meningkat mencapai $80 \%$. Dengan demikian, pada tindakan di siklus II para siswa akan terus berupaya untuk meningkatkan usahanya dengan menampilkan keterampilan berbicara yang baik.

\section{Kendali Diri}

Aspek ini mengacu kepada kemampuan siswa untuk merasakan/mengidentifikasi penyebab keberhasilan atau kegagalan pembelajaran. Berdasarkan hasil kuesioner motivasi berbicara peningkatan skor untuk aspek kendali diriini sebesar 13. Skor rata-rata pada pratindakan 55 kemudian meningkat pada siklus I menjadi 69 dan pada siklus II meningkat menjadi 70,5 . Dengan demikian, rata-rata siswa dapat dimaknai memiliki kecakapan dan kesiapan penuh untuk berhasil dalam kegiatan diskusi serta debat.

\section{Regulasi diri}

Harlen (2006:67) menegaskan bahwa siswa yang memiliki regulasi diri berarti ia memiliki kesadaran penuh dan tanggung jawab untuk melakukan dan meningkatkan pembelajaran yang dilakukan. Berkaitan dengan teori tersebut, hasil penelitian ini pun menunjukkan peningkatan skor pada aspek ini. Semula pada pratindakan skor rata-rata hanya 55 lalu pada siklus I terjadi peningkatan menjadi 69 dan pada siklus II menjadi 73,3. Peningkatan skor rata-rata pada aspek ini memperkuat teori di atas bahwa setelah diadakan tindakan melalui penerapan penilaian autentik terjadi pula peningkatan kesadaran, perhatian, dan tanggung jawab siswa untuk meningkatkan kualitas pembelajaran berbicara.

Berdasarkan aspek atau komponen motivasi berbicara di atas, skor rerata baik nilai akhir maupun skor per kategori mengalami peningkatan. Peningkatan tersebut bertahap mulai dari pratindakan ke siklus I dan siklus I ke siklus II. Pada siklus II skor rerata semua komponen motivasi berbicara telah mencapai skor 70, yang berarti secara produk dapat dikatakan telah berhasil. Melalui hasil penelitian ini, secara produk terlihat jelas bahwa pembelajaran berbicara dengan menerapkanpenilaian autentik dapat meningkatkan motivasi berbicara.

\section{Peningkatan Skor Aspek-Aspek Keterampi- lan Berbicara}

Aspek Bahasa

Aspek bahasa dalam keterampilan berbicara siswa merupakan aspek yang peningkatannya paling rendah. Sejak pratindakan hingga siklus II peningkatan pada aspek bahasa sebesar 1,24. Berdasarkan hasil penilaian melalui rubrik penilaian keterampilan berbicara sebagian besar siswa masih merasa sulit untuk mengungkapkan idenya dengan kosakata yang tepat. Selain itu, ungkapan-ungkapan yang digunakan untuk menyatakan pendapat kurang bervariasi. Memang ada beberapa siswa yang penggunaan bahasanya relatif baik. Akan tetapi jika dilihat berdasarkan skor rata-rata tetap saja siswa kelas VIII A kemampuan penggunaan bahasanya kurang merata.

Selanjutnya, pada siklus I skor aspek bahasa ini mulai mengarah kepada peningkatan. Sebagian besar siswa tidak mengalami hambatan dalam memilih kosakata untuk mengungkapkan ide. Hal ini dikarenakan topik yang didiskusikan merupakan pilihan siswa sehingga siswa memiliki latar belakang pengetahuan yang memadai. Latar belakang pengetahuan itulah yang memudahkan siswa untuk mengungkapkan pendapat.

\section{Aspek Ide/Isi}

Aspek isi atau ide dalam keterampilan berbicara siswa pada akhir siklus II menunjukkan peningkatan yakni sebesar 1,60. Peningkatan skor ini sekaligus menunjukkan bahwa desain pembelajaran berbicara terutama bentuk penilaian yang digunakan membawa perubahan pada kualitas isi pembicaraan siswa. Tindakan yang dilakukan pada siklus I dan II dalam menerapkan penilaian autentik memang diupayakan memenuhi prinsip desain pembelajaran berbicara Brown (2001:275-276). Prinsip yang dimaksud adalah prinsip yang mengakomodasi kebutuhan peserta didik, dari pembelajaran bahasa yang berfokus pada ketepatan makna dan yang berfokus pada kelancaran menyampaikan pesan dalam interaksi.

Prinsip tersebut dipenuhi dengan menyediakan beberapa topik diskusi/debat untuk dipilih oleh siswa. Selain itu, guru juga memberi 
keleluasaan bagi siswa untuk mengeksplorasi materi-materi yang terkait dengan topik sebelum diskusi/debat berlangsung. Dengan demikian, para siswa bisa lebih siap dan memiliki cukup bekal untuk melakukan diskusi/debat. Alhasil, ide-ide dapat diungkapkan dengan lancar dan bermakna.

\section{Aspek Perilaku Nonverbal}

Target pada aspek ini adalah siswa memiliki sikap yang baik saat berbicara. Dengan kata lain, sikap-sikap siswa ketika berbicara haruslah berupa sikap yang mendukung isi pembicaraan. Pada tahap pratindakan aspek perilaku nonverbal siswa ditunjukkan dengan skor rata-rata 1,28. Hal ini menunjukkan bahwa sikap-sikap siswa seperti kontak mata, ekspresi wajah, gerakan tangan, dan gestur kurang mendukung isi pembicaraan. Namun, setelah dilakukan beberapa tindakan pada siklus I terjadilah peningkatan skor rata-rata menjadi 3,52. Selanjutnya, pada siklus II skor rata-rata aspek ini malah mengalami penurunan menjadi 3.

Berdasarkan hasil refleksi di siklus II, penurunan skor rata-rata aspek perilaku nonverbal ini dikarenakan ada beberapa siswa yang merasa cemas dan grogi. Kecemasan tersebut muncul karena siswa merasa belum menyiapkan materi sesuai tema debat sehingga perilaku nonverbalnya saat berbicara menunjukkan hal-hal yang kurang sesuai.

\section{Aspek Kelancaran}

Berdasarkan hasil refleksi faktor pemicu aspek kelancaran meningkat, yaitu (1) topiktopik yang dijadikan bahan diskusi merupakan topik yang paling dekat dengan kehidupan sehari-hari siswa; (2) siswa memiliki latar belakang pengetahuan yang memadai tentang topik; (3) bentuk penilaian yang menuntut keaktifan berbicara; dan 4) desain pembelajaran berbicara yang mampu membangkitkan motivasi berbicara.

\section{Keterbatasan Penelitian}

Penelitian yang dilakukan di kelas VIII A SMP Islam Al Azhar 26 Yogyakarta ini tentu memunyai keterbatasan, antara lain: dampak variabilitas waktu tindakan, gambaran motivasi berbicara siswa kelas VIII A dalam penelitian ini tidak bisa digeneralisasikan untuk subjek lain, kesungguhan dan motivasi belajar siswa saat penelitian dilakukan merupakan hal-hal yang berada di luar jangkauan peneliti untuk mengontrolnya, kesungguhan observer dalam mengamati proses belajar siswa saat penelitian dilakukan berada pula di luar jangkauan peneliti untuk mengontrolnya, kesungguhan dan kejujuran siswa dalam mengisi kuesioner motivasi berbicara saat penelitian dilakukan merupakan hal-hal yang berada di luar jangkauan peneliti untuk mengontrol secara penuh.

\section{SIMPULAN}

Penelitian tindakan kelas ini menunjukkan bahwa kualitas proses pembelajaran berbicara dengan adanya penerapan penilaian autentik mengalami peningkatan dari pratindakan hingga akhir siklus II. Indikator keberhasilan proses ditunjukkan Situasi pembelajaran berbicara dalam penelitian ini cenderung mengarah kepada keadaan positif. Antusiasme, perhatian, peran aktif, dan situasi pembelajaran siswa dari pratindakan hingga akhir siklus II meningkat menjadi $80-85 \%$. Di samping itu, kebiasaankebiasaan negatif yang mengganggu kegiatan berbicara siswa semakin berkurang. Sebagian besar siswa sudah mampu menyampaikan lebih dari tiga pertanyaan, pernyataan, dan tanggapan. Selain itu, durasi waktu berbicara sebagian besar siswa sudah lebih dari satu menit. Sementara itu, hasil kuesioner menunjukkan motivasi berbicara siswa selama siklus per siklus mengalami peningkatan. Setelah tindakan dilaksanakan, enam komponen motivasi tersebut masing-masing sudah mencapai skor rerata 70 s.d. 76 . Di samping itu, skor rata-rata kelas untuk variabel motivasi berbicara juga mengalami kenaikan.

Hasil tes keterampilan berbicara menunjukkan bahwa skor rata-rata keterampilan berbicara pada pratindakan hanya 34,50 kemudian menjadi 63, 08 di siklus I dan 73,78 di siklus II. Di samping itu, skor tiap aspek keterampilan berbicara mengalami peningkatan siklus per siklus.

Seiring peningkatan skor rata-rata keterampilan berbicara nilai standar deviasi siklus per siklus cenderung semakin mengecil. Hal ini menunjukkan bahwa variasi subjek penelitian di akhir siklus semakin homogen. 
Berdasarkan uraian di atas, penelitian yang dilakukan dengan menerapkan penilaian autentikdapat meningkatkan kualitas pembelajaran berbicara baik secara proses dan hasil. Jadi, upaya penerapan penilaian autentik dalam pembelajaran berbicara siswa kelas VIII A tersebut dapat dikatakan berhasil. Hal ini disebabkan target-target penelitian tindakan kelas ini dapat tercapai sesuai harapan.

\section{Ucapan Terima Kasih}

Artikel ini disusun berdasarkan tesis yang telah diujikan dan direvisi. Oleh karena itu, saya mengucapkan terima kasih kepada pembimbing Prof. Dr. Zamzani dan dewan penguji tesis yang telah memberi masukkan dan saran terhadap tesis saya. Dengan bantuan tersebut artikel hasil penelitian ini dapat diwujudkan.

\section{DAFTAR PUSTAKA}

Brown, H. D. 2001. Teaching by Principles an Interactive Approach to Language Pedagogy. San Fransisco: Longman.

Donoghue, M. R. 2009. Language Arts Integrating Skills for Classroom Teaching. Los Angeles:Sage Publications.

Hamalik, Oemar. 2011. Proses Belajar Mengajar. Jakarta: PT Bumi Aksara

Harlen, Wynne. 2006. The Role of Assessment in Developing Motivationf for Learning.
Dalam John Gardner. Ed. Assessment and Learning: An Introduction. (pp. 61-80). London: Sage Publications.

Madya, Suwarsih. 2006. Teori dan Praktik Penelitian Tindakan. Yogyakarta: Alfabeta.

Nurgiyantoro, Burhan. 2012. Penilaian Pembelajaran Bahasa Berbasis Kompetensi. Yogyakarta: BPFE

Sayuti, Suminto A. 2011. Menuju pengajaran bahasa dan sastra yang bermakna. Dalam Badan Pengembangan dan Pembinaan Bahasa. (2011). Risalah Kongres Bahasa Indonesia VIII "Pemberdayaan Bahasa Indonesia Memperkukuh Budaya Bangsa dalam Era Globalisasi (Pp.807-819). Jakarta: Kementerian Pendidikan dan Kebudayaan 2011.

Suparno. 2011. Pengajaran bahasa Indonesia di sekolah. Dalam Badan Pengembangan dan Pembinaan Bahasa. (2011). Risalah Kongres Bahasa Indonesia VIII "Pemberdayaan Bahasa Indonesia Memperkukuh Budaya Bangsa dalam Era Globalisasi (pp.820). Jakarta: Kementerian Pendidikan dan Kebudayaan 2011.

Suyata \& Nurgiyantoro. 2009. Pengembangan Model Asesmen Otentik dalam Pembelajaran Bahasa. Cakrawala Pendidikan, XXVIII, p. $224-237$ 